\title{
Sinc ウェーブレットを用いた非定常性を有する模擬地震動作成手法の研究 ARTIFICIAL GROUND MOTION WITH NON-STATIONARITY GENERATED BY THE SINC WAVELET
}

\author{
前田 寿 朗*, 佐々木 文夫**, 山本佳 史*** \\ Toshiro MAEDA, Fumio SASAKI and Yoshifumi YAMAMOTO
}

\begin{abstract}
We have proposed a new method of constructing artificial ground motion with non-stationarity, which is necessary to evaluate the frequency selective resonance of non-linear structures. The wavelet transform with the Sinc wavelet is used to decompose signal into band-limited wavelets with temporal shifts, thus expressing the non-stationarity. Squared wavelet coefficients are modeled by the normal distribution along time axis, with the acceleration power, the temporal centroid, and the temporal variance evaluated for magnitudes and epicentral distances. Artificial ground motion is generated by the inverse wavelet transform to show the non-stationarity inferred from wave propagation and statistically anticipated attenuation relations.
\end{abstract}

Keywords : $\quad$ Wavelet Analysis, Sinc Wavelet, Group Delay Time, Artificial Ground Motion, Non-stationality, Regression Analysis. ウェーブレット解析, Sinc ウェーブレット, 群遅延時間, 模擬地震動, 非定常性, 回帰分析

\section{1. 研究の目的}

大地震動を受ける構造物が弾塑性応答する場合，地震動に対する応答 によって構造物の振動特性が時々刻々変化すると同時に, 応答に寄与する 振動数成分が構造物の振動特性により選択される1).したがって，構造物の 応答や損傷を評価する上で, 入力地震動の振動数成分に関する非定常性 は振幅同様に重要である ${ }^{2), 3)}$. 設計用入力地震動の作成手法には理論的な 方法と経験的な方法があり，経験的な方法の多くはマグニチュードと震源距 離等の数少ないパラメータで地震動の态答スペクトルを表現する. 応答スペ クトルに適合した模擬地震動の時刻歴を生成するには，一般に一様乱数位 相と包絡形を用いた正弦波重ね合わせ法が用いられているが, 同手法の包 絡形が振幅の非定常性をモデル化するのに対して, 一様乱数で表される位 相は振動数成分に関する非定常性を表現できない ${ }^{4)}$. したがって，振動数成 分に関する非定常性を表現できる, 模擬地震動作成手法の開発が望まれて いる.

和泉・勝倉 ${ }^{2}$ は, 時刻歴データの自乗の時間軸に沿うた積分值, 1 次モ一

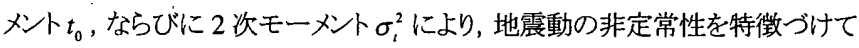
いる.これらの振動数領域での表現より，時刻歷自乗の重心は群遅延時間に フーリエスペクルル振幅自乗で重みをつけた積分值 $\mu_{\mathrm{rgr}}$ で表され，時刻歴自 乗の分散はフーリエスペクトル振幅の微分の自乗積分 $\sigma_{d \alpha}^{2}$ と, 群遅延時間と 重心の差の自乗にフーリエスペクトル振幅自乗の重みをつけた積分 $\sigma_{\mathrm{gr} r}^{2}$ の

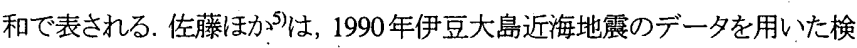
討により, 以上のパラメータ評価における重みつき積分の必要性を示して
いる. 同時に $\sigma_{r}^{2}$ における $\sigma_{d \Lambda}^{2}$ の寄与にも言及しているが, その後の日本全 国での回帰分析検討では $\sigma_{d \Lambda}^{2}$ の寄与を考虑の外におき， $\mu_{t g r}$ と $\sigma_{t g r}^{2}$ のモデ ル化により位相で非定常性を表した模擬地震動作成手法を論じた ${ }^{9}$. しかし ながら，佐藤ほがの伊豆大島近海地震での $\sigma_{d \wedge}^{2}$ の寄与が約 $20 \%$ あ゙ったの に対し, 和泉・勝倉 ${ }^{2)}$ の宮城県沖地震の検討では約 $50 \%$ 寄与であったこと を考慮すると， $\sigma_{d A}^{2}$ の奇与を評価する必要性が考えられる。

以上の手法がフーリエ解析のみを用いるのに対し，1980 年代初めに考案 されたウェーブレット解析は時刻歴をウェーブレット特有の振動数帯域に分 離でき, その分離された信号はウェーブレットの時間移動による重ね合わせ で表現できるので, 振動数帯域ごとの非定常性の検討に最適なツールと考 えられるク . 佐藤ほか ${ }^{8}$ は, ウェーブレット变換で分離した振動数帯域ごとに群 遅延時間をモデル化し，佐藤ほかりと同様な方法により模擬地震動を合成す る方法を示しており, そこでのウェーブレット変換は一種のバンドパスフィルタ としての役割を果たしているように思われる.

他方, 佐藤・室野 ${ }^{9}$ は単に振動数帯域ごとの地震動の位相特性をモデル 化するのみならず，位相特性と加速度パワーより対応するウェーブレット倸数 を求める方法も示している. 同論文中では, 複数の地震の観測記録を回帰分 析して $\mu_{t g r} ， \sigma_{r g r}^{2}$ ならびに加速度パワーをモデル化し，乱数を用いて発生し た群遅延時間より位相スペクトルを求め, 非定常性をウェーブレット係数列を 用いて表現している. しかしながら，それれらは群遅延時間のみから求められて おり上述の $\sigma_{d 4}^{2}$ の影響には言及していない. また, モデル化パラメータがウェ ーブレット変換で分離した振動数帯域ごとの群遅延時間の平均と分散ならび

\footnotetext{
本論文は，文献11)に新たな考察を加えて加簕したものである。

* 早稲田大学理工学部建築学科 博士 (工学)

** 鹿島 I.T.ソリューション部 博士 (数理科学)

*** 鹿島 I.T.ソリューション部 修士(工学)
}

Dept. of Architecture, Waseda University, Dr. Eng.

Kajima Corporation, Ph. D. (Mathematical Sciences)

Kajima Corporation, M. Eng. 
に加速度パワーの3つの量に限られているが, その後の処理に最小自乗法 によるウェーブレット倸数列の評価といら高振動数帯域では大きな行列の演 算が必要となり，実用性を損ならおそれがある. 以上の論文が群遅延時間を 主要なモデル化対象としたのに対し，伊山・桑村 ${ }^{10}$ 泫ェーブレット係数の自 乗和が振動数帯域でのエネルギーに対応することを用いて, 累積エネルギ 一入力, エネルギー入力卓越時刻ならびにエネルギー入力率のモデル化に よりウェーブレット係数列を発生する方法を示している. そこでは, 時間領域 での分解能を重視した Daubechies のウェーブレットを使用している.

模擬地震動の非定常性のモデル化を群遅延時間のみから行うう ${ }^{8)}$ とすると， フーリエスペクトル振幅の情報の欠落による影響を避けることができない. ウ エーブレット解析を用いると群遅延時間に依存せずに非定常性をモデル化 することができるが，現状においては群遅延時間を介在せずに観測記録から ウェーブレット係数を直接モデル化する試みは行われていない. 本論文では, 地震動記録の回帰分析によりウェーブレット係数を直接的にモデル化し, 非 定常性を有する模擬地震動を作成する手法を提案する ${ }^{11}$. まず, ここでは, ウェーブレット変換により分離された振動数帯域ごとの波形に対して計算を 行なうため，振動数帯域の重なりが極小の Sincウェーブレットをマザーウェー ブレットに採用し，このウェーブレットを用いたウェーブレット変換の効率的な 計算方法を示す，つぎに, 時刻歴データのエネルギーならびに経時特性パ ラメータ $t_{0}$ および $\sigma_{t}^{2}$ と同ウェーブレット係数の自乗の関係を明らかにする. 最後に, 例題として複数の地震の観測記録よりウェーブレット倸数の自乗の 時間軸上の分布を回帰し，その回帰結果に基づいて作成した想定地震の模 擬地震動を例示する.

\section{Sinc ウェーブレット}

直交ウェーブレットを構成する一つの手法である多重解像度解析 $(\mathrm{MRA})^{122,13)}$ では、スケーリング関数をあらかじめ決める必要があるが, Sinc 関 数 14 , 15)

$$
\begin{aligned}
& \operatorname{Sinc}(t)=\sin \pi t / \pi t \\
& \hat{\operatorname{Sinc}}(\omega)=1(-\pi \leq \omega<\pi), 0 \text { (otherwise) }
\end{aligned}
$$

は, その正規直交性からスケーリング関数となり得る関数である.ここで“は フーリエ領域を表わすものとする. Sinc 関数を用いると任意の $\pi$ 帯域制限関 数 $f(t)$ に対して Shannon の標本化定理

$$
f(t)=\sum_{k=-\infty}^{\infty} f(k) \operatorname{Sin} c(t-k)
$$

が成立することから, Sinc 関数は Shannon のスケーリング関数とも呼ばれる16. 本研究では, デー夕を離散量としたときに、ウェーブレット変換·逆変換にお いて, 再構成を可能にするため, フーリエ領域における Sinc 関数を

$$
\hat{\operatorname{Sinc}}(\omega)=\left\{\begin{array}{lc}
1 & (|\omega|<\pi) \\
1 / \sqrt{2} & (|\omega|=\pi) \\
0 & \text { (otherwise) }
\end{array}\right.
$$

と定義する. この関数をスケーリング関数として, 通常の MRA による正規直 交基底を構成する操作を行うことにより得られるマザーウェーブレット $\psi(t)$ は， 結果のみを記すと以下のような形で表現される。

$$
\begin{aligned}
& \psi(t)=\frac{\sin \pi(t-1 / 2)}{\pi(t-1 / 2)}-2 \frac{\sin 2 \pi(t-1 / 2)}{2 \pi(t-1 / 2)} \\
& \hat{\psi}(\omega)=-\exp (-i \omega / 2) \hat{\Psi}(\omega) \\
& \text { 但し } \hat{\Psi}(\omega)=\left\{\begin{array}{cl}
1 & \pi<|\omega|<2 \pi \\
1 / \sqrt{2} & |\omega|=\pi, 2 \pi \\
0 & \text { otherwise }
\end{array}\right.
\end{aligned}
$$

本研究ではこのマザーウェーブレットを Sinc ウェーブレットと呼ぶことにす る. 尚, このマザーウェーブレットを原点方向に $1 / 2$ だけ移動させた関数によ
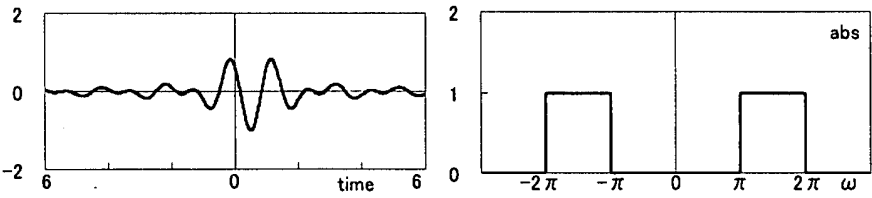

図 1 時間領域と振動数領域での Sinc ウェーブレット

って作られる基底は Littlewood-Paley 基底と呼ばれている ${ }^{12)}$.

Sinc ウェーブレットの特徵は, 時間領域においては非常に滑らかな関数で 無限回微分可能であること，また，そのフーリエ変換(6), (7)式から明らかなよ うに振動数領域においてコンパクトサポートを持つことであり, しかも Sinc ウェ ーブレットによる族(wavelets),

$$
\left\{\psi_{j, \ell}(t): \psi_{j, \ell}(t)=2^{j / 2} \psi\left(2^{j} t-\ell\right), j, \ell \in Z\right\}
$$

を考えると, 添字 $j$ (レベル $j$ )を固定した時の振動数領域 $\omega$ でのサポート区 間は $\left[2^{j} \pi, 2^{j+1} \pi\right]$ となることから(一般に $T$ を時刻歴データの継続時間とした とき，振動数領域 $\mathrm{Hz}$ におけるサポート区間は $\left[2^{j-1} / T, 2^{j} / T\right]$ となる), $\hat{\psi}_{j, k}(\omega)$ と市 ${ }_{j+1, \ell}(\omega)$ とのサポートの重なりは端の点だけであるということである. サポート区間から判るように, ウェーブレットの添字 $j$ を変化させることは振動 数帯が変化することに対応する. また, 添字 $l$ を変化させることは, 時間軸上 での移動(シフト)に対応している. 本研究では, 上述したようにサポートの重 なりが端の点のみである事, および関数形状が解析的に非常に単純な形で 表現できる事から Sinc ウェーブレットをウェーブレット解析の核関数として採 用する. 図 1 には参考のために Sinc ウェーブレットの時間, 振動数両領域で の形を示してある.

$$
\begin{aligned}
& \text { ところで一般に、時刻歴波形 } f(t) \text { の直交ウェーブレット变換·逆変換は } \\
& \alpha_{j, \ell}=\int_{-\infty}^{\infty} f(t) \overline{\psi_{j, \ell}(t)} d t \\
& f(t)=\sum_{j=0}^{\infty} \sum_{\ell=0}^{2 l_{-1}} \alpha_{j, \ell} \psi_{j, \ell}(t)
\end{aligned}
$$

で定義される ${ }^{12), 17)}$.ここで一 は複素共役を表わす. (9)式を直接数值計算 することももちろん理論的には可能である. しかし, Sinc ウェーブレットは振動 数領域において不連続性を有していることから，時間領域において $t \rightarrow \pm \infty$ としたときの減衰の早さは $1 / t$ と二乗可積分関数としては非常に遅いため, (9)式の直接数值計算は収束性や打切り誤差の問題により数值計算上困難と なることが多い.ここでは時刻歴波形に周期性(便宜的にここでは周期1として 定式化を行う)を仮定し,フーリエ変換を用いて効率的に計算する方法につ いて述べる.

まず時刻歴波形はフーリエ級数展開により,

$$
\begin{aligned}
& f(t)=\sum_{k=-\infty}^{\infty} a_{k} \exp (2 i \pi k t) \\
& \hat{f}(\omega)=2 \pi \sum_{k=-\infty}^{\infty} a_{k} \delta(\omega-2 \pi k)
\end{aligned}
$$

と表わせる.ここで $a_{k}$ はフーリエ係数であり、 $\delta$ は Dirac のデル夕関数である. (8)式の Sinc ウェーブレットは

$$
\hat{\psi}_{j, \ell}(\omega)=-2^{-j / 2} \exp \left(-i \omega \ell / 2^{j}\right) \exp \left(-i \omega / 2^{j+1}\right) \hat{\Psi}\left(\omega / 2^{j}\right)
$$

とフーリエ変換されることを考慮に入れると，

$$
\begin{aligned}
\alpha_{j, \ell} & =1 / 2 \pi \int_{-\infty}^{\infty} \hat{f}(\omega) \overline{\hat{\psi}_{j, \ell}(\omega)} d \omega \\
& =-\int_{-\infty}^{\infty}\left\{\sum_{k=-\infty}^{\infty} a_{k} \delta(\omega-2 \pi k)\right\} 2^{-j / 2} \\
& =-\sum_{k=-\infty}^{\infty} 2^{-j / 2} a_{k} \exp \left(2 \pi i k \ell / 2^{j}\right) \exp \left(i \pi k / 2^{j}\right) \hat{\Psi}\left(2 \pi k / 2^{j}\right)
\end{aligned}
$$

と表される. 上式を Sinc ウェーブレットのサポートを考慮に入れ, $k$ の正の部 分と負の部分に分ける. 


$$
\begin{aligned}
\alpha_{j, \ell}= & -2^{-j / 2} \sum_{k=0}^{2^{j}-1}\left\{a_{k} \exp \left(i \pi k / 2^{j}\right) \hat{\Psi}\left(2 \pi k / 2^{j}\right)\right\} \exp \left(2 \pi i k \ell / 2^{j}\right) \\
& -2^{-j / 2} \sum_{k=0}^{2^{j}-1}\left\{a_{-k} \exp \left(-i \pi k / 2^{j}\right) \hat{\Psi}\left(-2 \pi k / 2^{j}\right)\right\} \exp \left(-2 \pi i k \ell / 2^{j}\right) \\
& +2^{-j / 2} 2^{-1 / 2} a_{2^{j}}+2^{-j / 2} 2^{-1 / 2} a_{-2^{j}}
\end{aligned}
$$

さらに時刻歴波形 $f(t)$ を実数值関数と仮定することにより, フーリエ係数の 複素共役性が考慮でき,

$$
\begin{aligned}
\alpha_{j, \ell}= & -2^{-(j-2) / 2} \operatorname{Re}\left[\sum_{k=0}^{2^{j}-1}\left\{a_{k} \exp \left(i \pi k / 2^{j}\right) \hat{\Psi}\left(2 \pi k / 2^{j}\right)\right\} \exp \left(2 \pi i k \ell / 2^{j}\right)\right] \\
& +2^{-(j-1) / 2} \operatorname{Re}\left[a_{2^{j}}\right] .
\end{aligned}
$$

となる.ここで時刻歴波形が離散的に得られているとしたときには, 最大のレ ベルを計算するときの $a_{2^{j}}$ は Nyquist 振動数を計算する際のフーリエ倸数に なる.このとき式(16)での右辺第 2 項は $1 / \sqrt{2}$ 倍する必要がある. また時刻歷 波形の周期が $T$ のときは上式の $\alpha_{j, \ell}$ を単に $T^{1 / 2} \alpha_{j, \ell}$ とするだけでよい.

式(16)で右辺第一項は高速フーリエ逆変換を用いて計算が可能であり,こ うすると計算効率がよい. ウェーブレット逆変換に関してはデータ関数のフー リエ係数を効率よく求めることができる.ここでは結果のみを記す．

$$
a_{\ell}=-\sum_{j=0}^{\infty} 2^{-j / 2} \exp \left(-i \pi \ell / 2^{j}\right) \hat{\Psi}\left(2 \pi \ell / 2^{j}\right) \sum_{k=0}^{2^{j}-1} \alpha_{j, k} \exp \left(-2 \pi i k \ell / 2^{j}\right)
$$

上式で $k$ に関する和は高速フーリエ変換で求まる. $j$ に関してはサポート の特徵から意味のあるものは高々 2 個である。

\section{3. 時間軸上の拡がりとウェーブレシト係数}

\section{1 ウェーブレット係数による表現}

和泉・勝倉 ${ }^{2}$ および佐藤ほか ${ }^{5)}$ によると, 時刻歴波形 $f(t)$ の complex envelope $\bar{f}(t)$ の全エネルギー $\bar{E}$, 時間軸上の重心 $t_{0}=\mu_{\mathrm{rg} r}$ および分散 $\sigma_{1}^{2}$ は, $\omega_{N}$ を Nyquist.振動数, $f(t)$ および $\bar{f}(t)$ のフーリエ変換を

$$
\begin{aligned}
& \int_{-\infty}^{\infty} f(t) \exp (-i \omega t) d t=A(\omega) \exp \{-i \varphi(\omega)\} \\
& \int_{-\infty}^{\infty} \bar{f}(t) \exp (-i \omega t) d t=|\bar{F}(\omega)| \exp \{-i \varphi(\omega)\} \\
& \text { 但L, }|\bar{F}(\omega)|= \begin{cases}2 A(\omega) & \omega \geq 0 \\
0 & \omega<0\end{cases}
\end{aligned}
$$

\section{群遅延時間を}

$$
\operatorname{tg} r(\omega)=\frac{d \varphi(\omega)}{d \omega}
$$

として以下のように表される.

$$
\begin{aligned}
& \bar{E}=\int_{-\infty}^{\infty}|\bar{f}(t)|^{2} d t=\frac{1}{2 \pi} \int_{-\infty}^{\infty}|\bar{F}(\omega)|^{2} d \omega=\frac{2}{\pi} \int_{0}^{\omega_{N}} A(\omega)^{2} d \omega \\
& t_{0}=\mu_{\mathrm{tgr}}=\frac{1}{\bar{E}} \int_{-\infty}^{\infty} t|\bar{f}(t)|^{2} d t \\
& =\frac{1}{2 \pi \bar{E}} \int_{-\infty}^{\infty}|\bar{F}(\omega)|^{2} \operatorname{tgr}(\omega) d \omega \\
& =\frac{2}{\pi \bar{E}} \int_{0}^{\omega_{N}} A^{2}(\omega) \operatorname{tg} r(\omega) d \omega \\
& \sigma_{t}^{2}=\frac{1}{\bar{E}} \int_{-\infty}^{\infty}\left(t-t_{0}\right)^{2}|\bar{f}(t)|^{2} d t=\sigma_{t g r}^{2}+\sigma_{d A}^{2} \\
& \sigma_{t g r}^{2}=\frac{1}{2 \pi \bar{E}} \int_{-\infty}^{\infty}|\bar{F}(\omega)|^{2}\left\{\operatorname{tg}(\omega)-t_{0}\right\}^{2} d \omega \\
& =\frac{2}{\pi \bar{E}} \int_{0}^{\omega_{N}} A^{2}(\omega)\left\{\operatorname{tgr}(\omega)-\mu_{t g r}\right\} d \omega \\
& \sigma_{d \Lambda}^{2}=\frac{1}{2 \pi \bar{E}} \int_{-\infty}^{\infty}\left\{\frac{d|\bar{F}(\omega)|}{d \omega}\right\}^{2} d \omega=\frac{2}{\pi \bar{E}} \int_{0}^{\omega_{N}}\left\{\frac{d A(\omega)}{d \omega}\right\}^{2} d \omega
\end{aligned}
$$

ここで. complex envelope $\bar{f}(t)$ の重心と分散は時刻歷波形 $f(t)$ の重心と 分散に一致し; エネルギーは 2 倍となっている.

和泉・勝倉 ${ }^{2}$ の 1978 年宮城県沖地震の記録の分析において $\sigma_{\mathrm{tgr}}^{2}$ と $\sigma_{\mathrm{d} d}^{2}$ は 同程度であり; 佐藤ほかがの伊豆大島近海地震の周期 1 15 秒の成分の検 討において $\sigma_{t g r}^{2} か ゙ \sigma_{d 4}^{2}$ の.4 倍程度だった事例が報告されている. それらの文
献において， $\sigma_{r g}^{2}$ と $\sigma_{d \mu}^{2}$ の構成比の重要性が指摘されているが, 以後の検討 は行われていないようである. その理由として, 従来型の模擬地震動作成法 がターゲットスペクトルを仮定して始まる傾向にあり，付随した位相制御の観 点から $\operatorname{tg} r(\omega)$ が論じられること，ならびに表面波主体の検討であるため群速 度との対応に注目が集まることが挙げられる。

ここでは, 時刻歴波形 $f(t)$ をウェーブレット変換((16)式)，各レベル $j の$ ウェーブレット係数から求まる帯域制限された逆変換波 $f_{j}(t)$, 加速度パワ $-E_{j}$, 時間軸上の重心 $\mu_{j}$ ，ならびに分散 $\sigma_{i j}^{2}$ を以下の式で定義する.

$$
\begin{aligned}
& E_{j}=\int_{-\infty}^{\infty} f_{j}(t) \overline{f_{j}(t)} d t=\frac{1}{2 \pi} \int_{-\infty}^{\infty} \hat{f}_{j}(\omega) \overline{\hat{f}_{j}(\omega)} d \omega \\
& \mu_{j}=\frac{1}{E_{j}} \int_{-\infty}^{\infty} t f_{j}(t) \overline{f_{j}(t)} d t=\frac{i}{2 \pi E_{j}} \int_{-\infty}^{\infty} \frac{d \hat{f}_{j}(\omega)}{d \omega} \overline{\hat{f}_{j}(\omega)} d \omega \\
& \sigma_{j}^{2}=\frac{1}{E_{j}} \int_{-\infty}^{\infty}\left(t-\mu_{j}\right)^{2} f_{j}(t) \overline{f_{j}(t)} d t=\frac{1}{2 \pi E_{j}} \int_{-\infty}^{\infty} \frac{d \hat{f}_{j}(\omega)}{d \omega} \frac{\overline{d \hat{f}_{j}(\omega)}}{d \omega} d \omega-\mu_{j}^{2}
\end{aligned}
$$

これらの式に (17)式の $j$ を固定した連続スペクトルを代入し, Sinc ウェー ブレットが正規直交系であり，特にレベルを固定したとき，(13)式から

$$
\begin{aligned}
\int_{-\infty}^{\infty} \psi_{j, k}(t) \overline{\psi_{j, l}(t)} d t & =\frac{1}{2 \pi} \int_{-\infty}^{\infty} \hat{\psi}_{j, k}(\omega) \overline{\hat{\psi}_{j, \lambda}(\omega)} d \omega \\
& =\frac{2^{-j}}{2 \pi} \int_{-\infty}^{\infty} \exp \left\{-i \omega(k-l) / 2^{j}\right\}\left|\hat{\Psi}\left(\omega / 2^{j}\right)\right|^{2} d \omega \\
& =\delta_{k,}
\end{aligned}
$$

を満たすことを考慮すると，(27)〜(29)式はウェーブレット係数により以下の (31) (33)式で与えられる.

$$
\begin{aligned}
E_{j}= & \sum_{k=0}^{2^{j}-1}\left|\alpha_{j, k}\right|^{2} \\
\mu_{j}= & \frac{1}{E_{j}} \sum_{k=0}^{2^{j}-1} \sum_{l=0}^{2^{j}-1}\left(\frac{k}{2^{j}}+\frac{1}{2^{j+1}}\right) \alpha_{j, k} \alpha_{j, l,} \\
& \cdot \frac{2^{-j}}{2 \pi} \int_{-\infty}^{\infty} \exp \left\{-i \omega(k-l) / 2^{j}\right\}\left|\hat{\Psi}\left(\omega / 2^{j}\right)\right|^{2} d \omega \\
= & \sum_{l=0}^{2^{j}-1}\left\{\left(\frac{l}{2^{j}}+\frac{1}{2^{j+1}}\right)\left|\alpha_{j, l}\right|^{2}\right\} / E_{j} \\
\sigma_{j}^{2}= & \sum_{l=0}^{2^{j-1}}\left\{\left(\frac{l}{2^{j}}+\frac{1}{2^{j+1}}\right)^{2}\left|\alpha_{j, l}\right|^{2}\right\} / E_{j}-\mu_{j}^{2}
\end{aligned}
$$

(31)式はウェーブレットが正規直交系ならいつでも成立する関倸であり, 広 〈知られている ${ }^{17), 18)}$. また, (32)式は, ウェーブレットが正規直交系で, $t=1 / 2$ での詨称性が仮定できれば成立する. たとえば, Meyerのウェーブレット ${ }^{12), 17)}$ を用いても；(32)式は成立する. (33)式は Sinc ウェーブレット固有の関係式で ある.

(31)〜(33)式より，レベルjに対応した帯域制限波の加速度パワー，なら

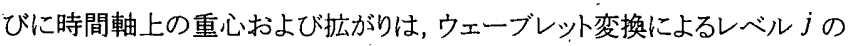
ウェーブレット係数から直接的に求められる.

尚, (31)〜(33)式では, 誘導の過程での煩雑さを避けるため， $f(t)$ を周期 1 秒の周期関数と仮定しているが, $f(t)$ が周期 $T$ 秒の周期関数であっても 結果は, $E_{j} \rightarrow E_{j} \cdot T, \mu_{j} \rightarrow \mu_{j} \cdot T, \sigma_{j}^{2} \rightarrow \sigma_{j}^{2} \cdot T^{2}$ となるだけである.

\section{2 観測記録に見られる関係}

(31)～(33)式のウェーブレット係数から定義されるパラメータを, 次章で使 用するデータセットの一部について求めた. 波形の原点は発震時刻である. なお，解析には原点がら 163.84 秒分のデー夕を使用じ, リンク効果による回り 込みを避けるために 163.84 秒分の 0 をデータの前に加えている. 図 2 に, 例 題に用いた兵庫県南部地震神戸海洋気象台(記録 $\mathrm{A}$ ) と北海道東方沖地震 根室気象台(記録 B)の各加速度 EW 成分を示寸. 図 3〜5に; 加速度パワ 一, 時刻歷重心, ならびに時刻歴標準偏差を示す。これらの図の綎軸はウェ 
ーブレットのレベルであり, 左右の図は図 2 の各加速度波形に対応する. ま た, 各レベルのサポート区間は, 表1中の振動数帯域と同じである.

ウェーブレット係数と時刻歷から求めたパワーは, 伊山・桑村 ${ }^{10} の$ 方法に おいてもほぼ一致することが確認されているが, 本報の Sinc ウェーブレットを 用いた場合のウェーブレット係数と時刻歷から求めたパワーは, 数值誤差を 除き完全に一致する(図 3 参照). 記録 B が $6.25 \mathrm{~Hz}$ 以下でほほ一定のパワー を有するのに対し，記録 $\mathrm{A}$ は 0.2 3Hzでパワーが卓越することが示されてい る. なお, 同図中ではレベル毎の比較を容易にするために, レベル $j$ に対応 する振動数䫌域のサポート区間で正規化した規準化加速度パワーを比較し た. ウェーブレット係数で表される規準化加速度パワーは, (34)式で定義す る.

$$
\tilde{E}_{j}=\frac{T}{2^{\prime}-2^{j-1}} \sum_{k=0}^{j^{\prime}=1}\left|\alpha_{j, k}\right|^{2}=\frac{T}{2^{j-1}} \sum_{k=0}^{j-1}\left|\alpha_{j, k}\right|^{2}
$$

図 4 に示す時刻歴重心の比較より，発震時刻から測った時間軸上の重心 とウェーブレット係数から求めた重心はよく対応する. また, 澤田 ${ }^{19}$ に従って求 めた群遅延時間に, スペクトル振幅自乗重み付き平均を施した結果も同程度 の值を示している.

図 5 に示す時間軸上の標準偏差について, 時刻歴とウェーブレット係数 から求めた結果はレベルの小さい範囲を除いてほぼ一致する. 一方群遅延 時間の標準偏差 $\sigma_{t g r}$ は, $\sigma_{d A}$ の寄与が含まれていない分だけ小さめであ る.

これらの図から, ウェーブレット倸数から評価された加速度パワーおよび 経時特性パラメータにより，地震動の非定常性が特徵づけられることがわかる. すなわち, 記録 $\mathrm{A}$ は 0.2〜 3Hz にパワーを有し,そのエネルギーは他の振動 数帯域と同様な時点に重心を持つが, 継続時間は他に比べて短いこと, また 記録 B は約 $6 \mathrm{~Hz}$ 以下でほぼ同様なパワーを有するが, $0.1 \sim 0.4 \mathrm{~Hz}$ の成分が 相対的に遅れ, $0.4 \mathrm{~Hz}$ 以下の成分の継続時間が振動数の低下とともに漸増 する様子を示すことができる。

図 5 に見られた $\sigma_{d A}$ の影響を検討するために, 4.で使用するデータセット のうちの, 兵庫県南部地震と北海道東方沖地震について, 全観測点の加速 度 $\mathrm{EW}$ 成分の $\sigma_{\mathrm{dA}}^{2} / \sigma_{t}^{2}$ と $\sigma_{\mathrm{tg}}^{2} / \sigma_{t}^{2}$ の平均值を図 6 に示寸. 同図より, これらの 記録の $\sigma_{d A}^{2} と \sigma_{t g r}^{2}$ は同等の奇与を示し, 波の拡がりに関する $\sigma_{d 4}^{2}$ の奇与を評 価する必要性を示唆している.

\section{4. 模擬地震動の作成}

前章で, 帯域制限された逆変換波 $f_{j}(t)$ の規淮化加速度パワー $\tilde{E}_{j}$ ，時 間軸上の重心 $\mu_{j}$ および拡がり $\sigma_{j}^{2}$ が, 各レベル $j$ のウェーブレット係数によ り表現できる事を示した.ここでは，その特性を利用して， $\mu_{j} ， \sigma_{j}^{2} ， \tilde{E_{j}}$ から ウェーブレット係数を作成する方法を示す.ささらに, 実際の観測記録に基づ いて, $\mu_{j}, \sigma_{j}^{2}, \tilde{E}$, をマグニチュード $\mathrm{M}$ と震央距離 $\Delta$ で重回㷌分析してこ れらの諸量をモデル化し，設定された $\mathrm{M}$ と $\Delta$ に対して模擬地震動を作成する 手法を提案する. なお, 本章の解析に使用するデータは, リンク効果による 回り込みを避けるために前章と同様の操作を加えている.

\section{1 ウェーブレット係数の作成}

各レベルjにおける $\mu_{j}, \sigma_{j}^{2}, \tilde{E}_{j}$ が与えられた時, それらから, ウェーブ レット倸数の絶対值の自乗值を発生する必要が生じる. 伊山・桑村 ${ }^{10}$ はエネ ルギー入力時刻歷とウェーブレット倸数の自乗累積值の関係から, 包絡形状 に関して, 3 角形分布を仮定しているが, 本論文では, 正規分布 $\left[\mu_{j}, \sigma_{j}^{2}\right]$ を 仮定した. 包絡形状の設定に関しては, 経験的な継続時間等の観点から, 今 後さらに検討が必要であろうと思われる. 次に, 各サポート区間の加速度パワ
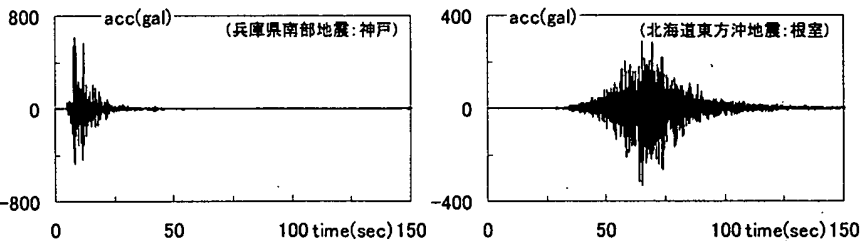

図 2 観測記録の加速度波形（左：記録 A，右：記録 B）
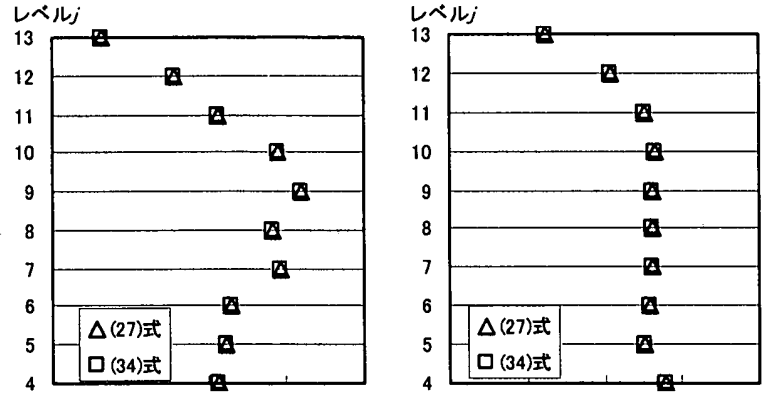

1.E-01 1.E+01 1.E+03 1.E+05 1.E+07 $\left(\mathrm{cm}^{2} / \mathrm{sec}^{2}\right)$ $\left(\mathrm{cm}^{2} / \mathrm{sec}^{2}\right)$

図 3 規準化加速度パワー（左：記録 $\mathrm{A}$ ，右 : 記録 $\mathrm{B})$
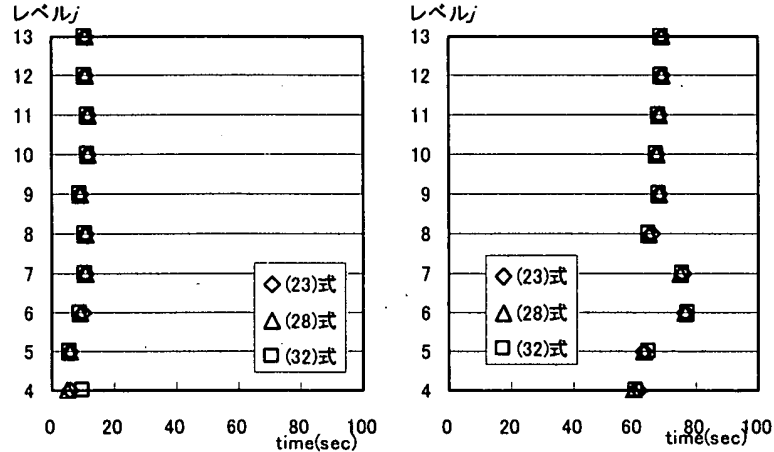

図 4 時刻歴重心 (左 : 記録 $\mathrm{A}$, 右 : 記録 B)
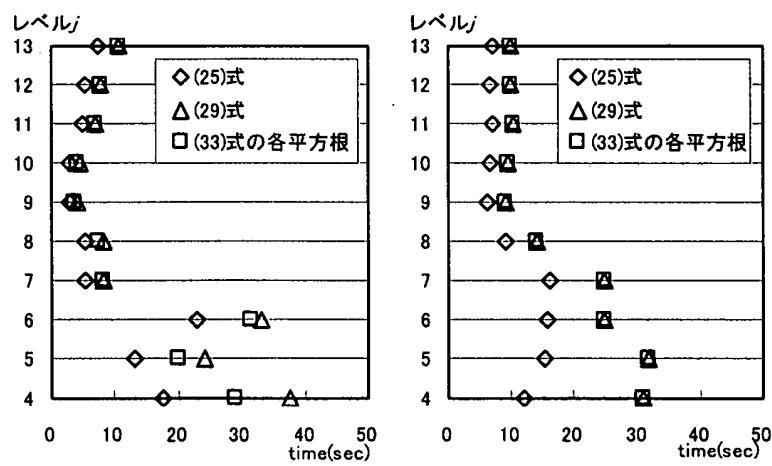

図 5 時刻歴標準偏差 (左：記録 $\mathrm{A}$, 右 : 記録 $\mathrm{B}$ )
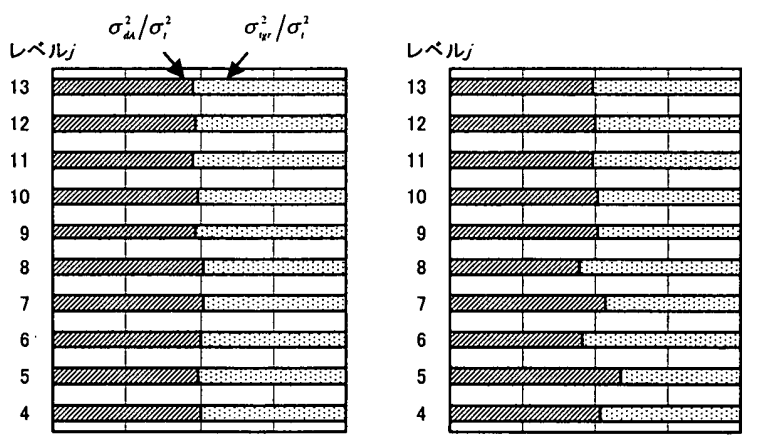

0* $25 \% \quad 50 \% \quad 75 \% \quad 100 \%$ 図 6 時刻歴分散平均値の比 (左 : 兵庫県南部地震, 右 $:$ 北海道東方沖地震) 
一が $E_{j}$ と等価になるようにウェーブレット係数の自乗値を与え, 伊山・桑村 ${ }^{10)}$ にならって, 一様乱数により符号を決定した. なお, ウェーブレット係数 $\alpha_{j, 1}$ は, (32)，(33)式に従って時刻 $\left(l / 2^{j}+1 / 2^{j+1}\right) \cdot T$ を代表するものとする.こ) のようにして得られたウェーブレット保数をウェーブレット逆変換し, 各レベル の逆変換波を合成して, 非定常性を有する時刻歴波形を作成する.

ここでは, 例として鹿児島県北西部地震(M=6.3)の K-NET 鹿児島県蒲生 観測点 $(\Delta=31 \mathrm{~km})$ の観測記録 $\left(\mathrm{NS}\right.$ 成分)から, 各レベルの $\mu_{j}, \dot{\sigma}_{j}^{2}, \tilde{E}$ を算 出し(表 1), 合成波と観測記録の比較を行った. 時刻歷波形, フーリエスペク トル振幅,ならびに連続ウェーブレット変換による時間一振動数領域でのウェ 一ブレット係数の絶対值を図 7 に示す.なお，波形の原点は発震時刻である。 また, 連続ウェーブレット变換は原点から 80 秒までの波形に対して適用し， 綖軸, 横軸の值はおおよその目安である. 時刻歷波形の包絡形および継続 時間, ならびに振動数特性とその非定常性は良く対応しこの例においては $\mu_{j}, \sigma_{j}^{2}, \tilde{E}$, から観測記録を概ね再現できた事がわかる. 以上より， $\mu_{j}$, $\sigma_{j}^{2}, \tilde{E}$, をマグニチュードと震央距離等に関して適切に設定することにより, 非定常性を反映した模擬地震動を作成できることが示された. ただし，本研 究では, ウェーブレット係数の絶対値の自乗の包絡形状を正規分布で表現し ているため, その包絡形状が正規分布と大きく異なる場合には, 分布形状を さらに検討する必要がある。

\section{2 重回帰分析}

本研究では, 佐藤 ${ }^{8}$ らの論文にならい, 重回帰分析を行った. 使用した地 震波は, 表 2 に示す地震のうち, 最大加速度が 30galを超えるデータで, その $\mathrm{M}$ との関係を図 8 に示す.

表 2 のデー夕に対して各ヶ $\mu_{j}, \sigma_{j}, E_{j}$ を求め, $\mathrm{M}$ とを説明変数として 次式により重回帰分析を行った.

$$
\begin{aligned}
& \mu_{j}=\alpha_{\mu j} \cdot 10^{\beta_{H^{\mathrm{M}}} \mathrm{M}} \cdot \Delta^{\gamma^{\prime \mu}} \\
& \sigma_{j}=\alpha_{o j} \cdot 10^{\beta_{\sigma} M} \cdot \Delta^{\sigma_{\sigma}} \\
& E_{j}=\alpha_{E j} \cdot 10^{\beta_{E} M} \cdot \Delta^{r_{E}}
\end{aligned}
$$

各レベルの回帰係数 $\alpha_{j}, \beta_{j}, \gamma$, と相関係数を表 3 に示す. $\mu_{j}, \sigma_{j}$ に関 する相関係数はレベルの増大とともに大きくなるが， $\tilde{E}, に$ 関する相関保数 には、レベルとの関係はあまり見られない. 参考に, 佐藤ら8)の方法にならい， $\operatorname{tg} r(\omega)$ の平均, 分散に関しても同様な重回帰分析を行った. 表 3 の括弧内 に示した $\operatorname{tg} r(\omega)$ の平均に関する相関係数は $\mu$ ，の相関係数と同様な值を示 したが, 分散に関する相関倸数は, ウェーブレット係数を用いた $\sigma_{j}$ よりやや 小さめになり，今回使用した地震波についてはウェーブレット倸数による時間 軸上の拡がりの評価がより安定した結果を示した。

$\mu_{j}, \sigma_{j}, \tilde{E}$, と対応する回㷌曲線の震央距離に関する比較を図 9 に示 す.震央距離の增大に伴って, 到達時刻が遅れるため $\mu_{j}$ が大きくなり, 地震 波が減衰することにより $\tilde{E}_{j}$ が小さくなる. また，地震波が散乱・分散するため 震央距離とともに $\sigma_{j}$ が大きくなる様子が見られるとともに， $E_{j}$, と同様にマグ ニチュードとともに $\sigma$,が大きくなる傾向が見られる.

\section{3 模擬地震動作成例}

表 4 の回帰係数を用い, 震央距離に関する非定常性の変化を考察するた めに, データが豊富で信頼性の高い $M=6.3$ において, $\Delta=10,30,100 \mathrm{~km}$ と した場合の模擬地震動を作成した。作成した模擬地震動の $j=7 \sim 13$ (約 $0.20 \sim 25 \mathrm{~Hz}$ )の帯域制限された逆変換波を図 10 に示す. $\Delta=10 \mathrm{~km}$ では各レ ベルの波形の重心はほぼ同じ時刻にあるが，震央距離が大きくなるに伴い， 各レベルの波形の重心時刻に差が生じ,レベルが小さいほど遅くなる傾向が 見られる.これは, 各レベルを代表する地震波動の伝播速度の違いを表して
表 1 鹿児島県北西部地震の

$\mu_{j}, \sigma_{j}, \tilde{E}_{j}$

\begin{tabular}{|c|c|c|c|c|}
\hline$j$ & $\mu_{j}$ & $\sigma_{j}$ & $\tilde{E}_{j}$ & 振動数帯域 $(\mathrm{Hz})$ \\
\hline \hline 4 & 13.29 & 42.19 & $2.37 \mathrm{E}-01$ & $0.02 \sim 0.05$ \\
\hline 5 & 14.73 & 21.94 & $1.08 \mathrm{E}+00$ & $0.05 \sim 0.10$ \\
\hline 6 & 10.82 & 20.93 & $9.09 \mathrm{E}+00$ & $0.10 \sim 0.20$ \\
\hline 7 & 27.56 & 24.09 & $8.40 \mathrm{E}+01$ & $0.20 \sim 0.39$ \\
\hline 8 & 28.84 & 15.51 & $4.52 \mathrm{E}+03$ & $0.39 \sim 0.78$ \\
\hline 9 & 23.86 & 9.71 & $7.89 \mathrm{E}+03$ & $0.78 \sim 1.56$ \\
\hline 10 & 16.24 & 5.10 & $2.63 \mathrm{E}+03$ & $1.56 \sim 3.13$ \\
\hline 11 & 13.90 & 3.51 & $5.56 \mathrm{E}+02$ & $3.13 \sim 6.25$ \\
\hline 12 & 12.50 & 3.02 & $3.39 \mathrm{E}+02$ & $6.25 \sim 12.5$ \\
\hline 13 & 12.60 & 3.43 & $1.75 \mathrm{E}+02$ & $12.5 \sim 25.0$ \\
\hline
\end{tabular}
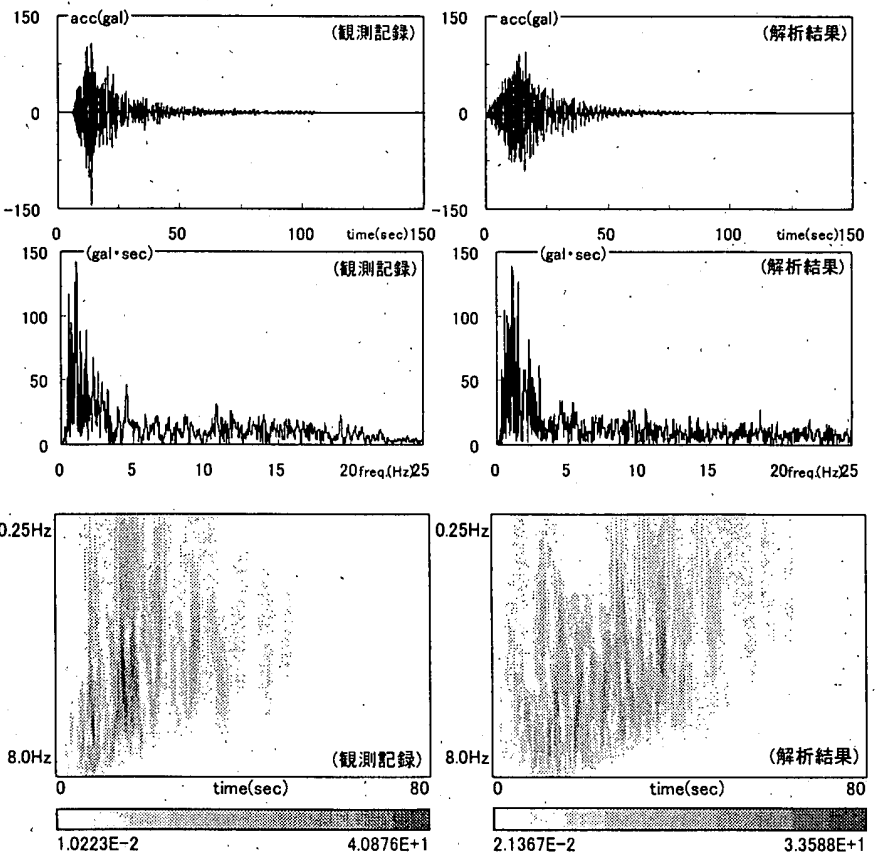

図7 鹿児島県北西部地震蒲生観測点の観測記録と解析結果 (上段 : 時刻歴，中段 : スペクトル，下段 : ウェーブレット変換)

表 2 使用地震波

\begin{tabular}{|c|c|c|c|c|}
\hline 発生日時 & 地震名 & $M$ & データ数 & 強震計 \\
\hline \hline $1993 / 7 / 12$ & 北海道南西沖地震 & 7.8 & 2 & 87 型 \\
\hline $1994 / 10 / 7$ & 北海道東方沖地震 & 8.1 & 18 & 87 型 \\
\hline $1994 / 12 / 28$ & 三陸はるが沖地震 & 7.5 & 14 & 87 型 \\
\hline $1995 / 1 / 17$ & 兵庫県南部地震 & 7.2 & 16 & 87 型 \\
\hline $1997 / 3 / 26$ & 鹿児島県北西部地震 & 6.3 & 69 & K-NET95 \\
\hline
\end{tabular}

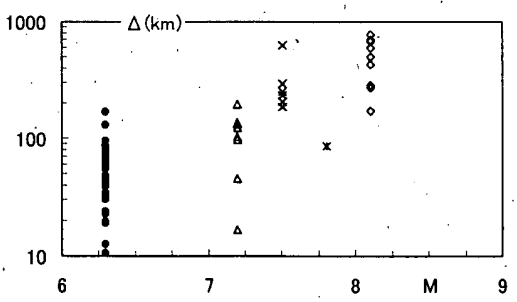

図8 使用データのMと $\Delta$ の関倸 
表 3 重回帰分析の結果(相関係数の括弧内は群遅延時間に対するもの)

\begin{tabular}{|r|c|c|c|c|c|c|c|c|c|c|c|c|}
\hline$j$ & \multirow{2}{*}{$\alpha_{\mu}$} & \multirow{2}{*}{$\alpha_{\sigma}$} & $\alpha_{\tilde{E}}$ & \multirow{2}{*}{$\beta_{\mu}$} & \multirow{2}{*}{$\beta_{\sigma}$} & \multirow{2}{*}{$\beta_{\tilde{E}}$} & $\gamma_{\mu}$ & $\gamma_{\sigma}$ & \multirow{2}{*}{$\gamma_{\tilde{E}}$} & \multicolumn{3}{|c|}{ 相関係数 } \\
\hline \hline 4 & 0.43 & 7.15 & $4.82 \mathrm{E}-13$ & 0.06 & 0.08 & 2.08 & 0.77 & 0.06 & -0.97 & $0.78(0.80)$ & $0.46(0.38)$ & 0.90 \\
\hline 5 & 0.20 & 1.55 & $3.55 \mathrm{E}-10$ & 0.10 & 0.14 & 1.85 & 0.79 & 0.15 & -1.33 & $0.93(0.92)$ & $0.69(0.71)$ & 0.86 \\
\hline 6 & 0.32 & 0.14 & $5.69 \mathrm{E}-07$ & 0.09 & 0.29 & 1.61 & 0.76 & 0.06 & -1.78 & $0.97(0.97)$ & $0.84(0.82)$ & 0.74 \\
\hline 7 & 0.72 & 1.19 & $9.36 \mathrm{E}-08$ & 0.06 & 0.12 & 1.91 & 0.70 & 0.18 & -2.21 & $0.97(0.96)$ & $0.76(0.76)$ & 0.75 \\
\hline 8 & 0.83 & 1.00 & $2.53 \mathrm{E}-04$ & 0.06 & 0.13 & 1.50 & 0.68 & 0.11 & -2.18 & $0.97(0.96)$ & $0.70(0.61)$ & 0.62 \\
\hline 9 & 0.66 & 0.81 & $8.11 \mathrm{E}-04$ & 0.05 & 0.10 & 1.51 & 0.73 & 0.18 & -2.25 & $0.98(0.98)$ & $0.75(0.63)$ & 0.66 \\
\hline 10 & 0.41 & 0.51 & $3.94 \mathrm{E}-04$ & 0.08 & 0.09 & 1.44 & 0.72 & 0.27 & -1.79 & $0.99(0.99)$ & $0.78(0.73)$ & 0.67 \\
\hline 11 & 0.31 & 0.11 & $1.86 \mathrm{E}-04$ & 0.09 & 0.19 & 1.46 & 0.72 & 0.22 & -1.83 & $0.99(0.99)$ & $0.87(0.81)$ & 0.74 \\
\hline 12 & 0.26 & 0.08 & $1.88 \mathrm{E}-02$ & 0.10 & 0.19 & 1.16 & 0.71 & 0.29 & -2.22 & $0.99(0.99)$ & $0.90(0.85)$ & 0.62 \\
\hline 13 & 0.20 & 0.07 & $4.45 \mathrm{E}+00$ & 0.11 & 0.19 & 0.67 & 0.74 & 0.33 & -2.38 & $0.99(0.99)$ & $0.88(0.83)$ & 0.57 \\
\hline
\end{tabular}
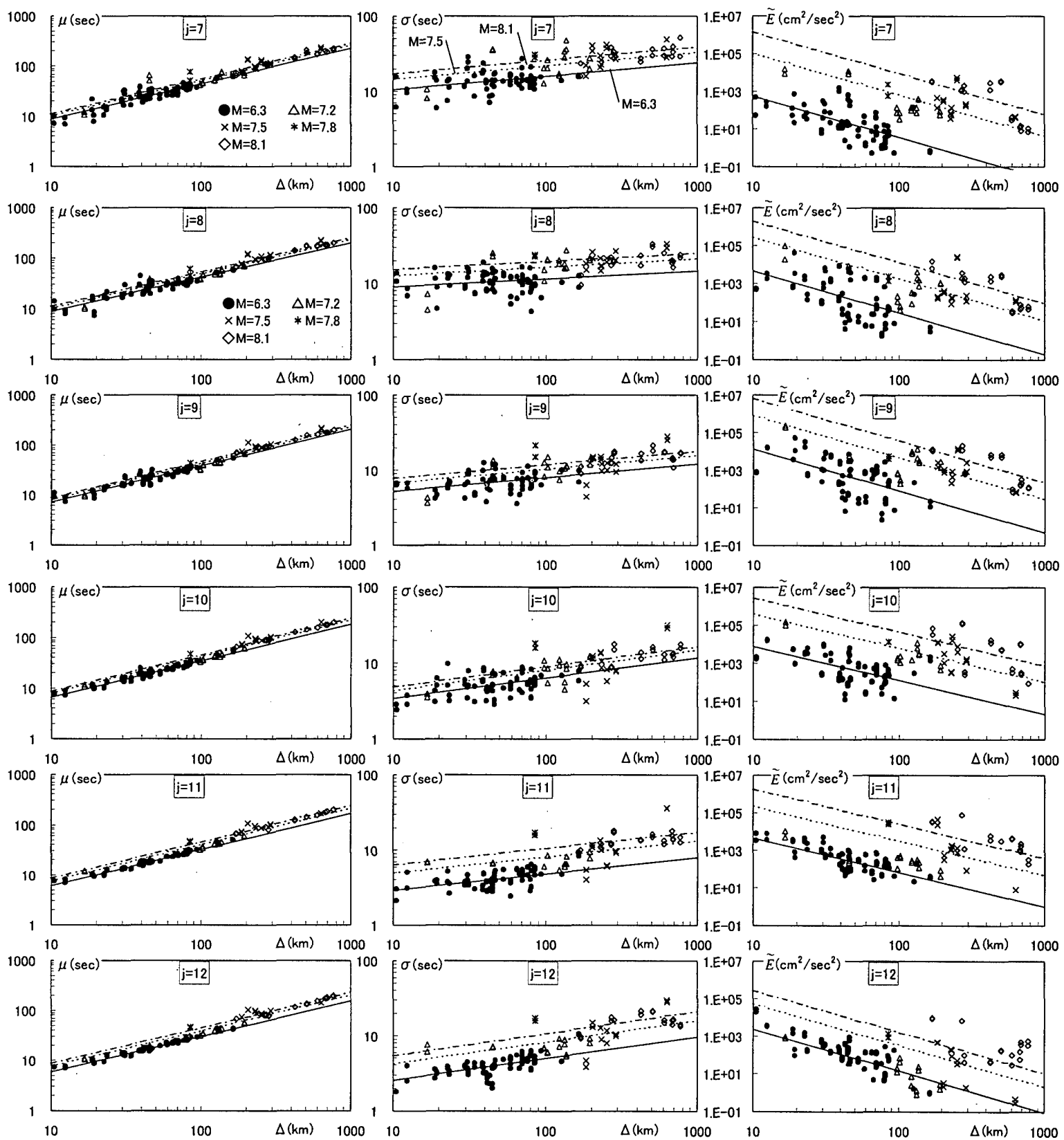

図 $9 j=7 \sim 12$ の重回帰分析結果( 左: $\mu_{j}$, 中央: $\sigma_{j}$, 右 : $\tilde{E}_{j}$ ) 

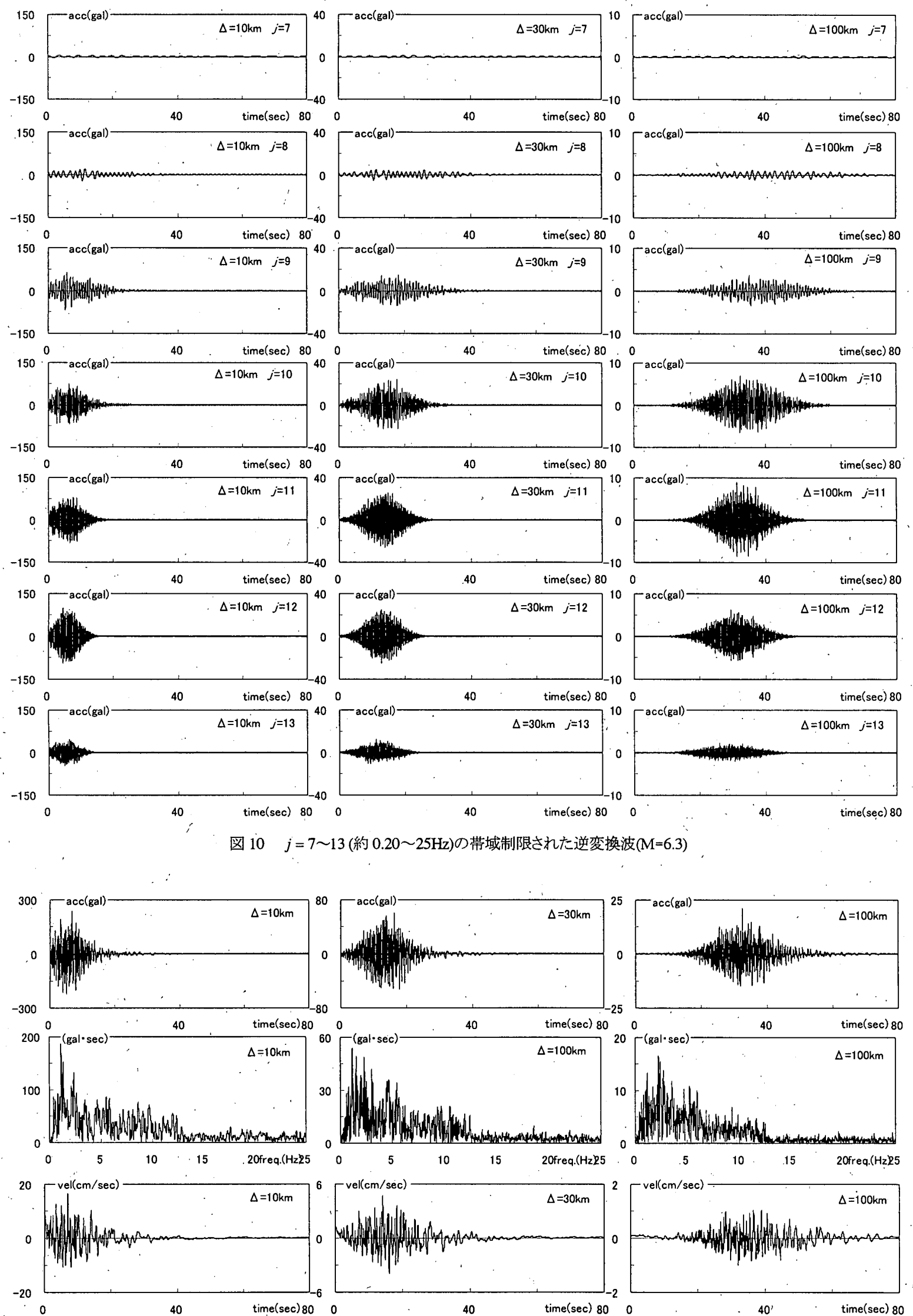

図 11 模擬地震動作成例( $\mathrm{M}=6.3)$

(上段 : 加速度, 中段 : 加速度フーリエスペクトル, 下段 : 速度) 
おり, 長周期成分ほど小さな伝播速度を示している. 長周期成分が遅れて現 れる傾向は, 既に, 伊山・桑村 ${ }^{20)} か ゙$ 行なった 1995 年兵庫県南部地震のウェー ブレット解析でもとらえられており，佐藤·室野·西村8)も同様の結果を得てい る.

また, 震央距離の增大に伴って，いずれのレベルの継続時間も増大する 様子が見られる.これは, 伝播距離の増大に伴って地震波の散乱および分 散がより顕著になることを表現している.

図 11 にすべてのレベルを合成した模擬地震動の加速度時刻歷波形とつ 一リエスペクトル振幅, およびその速度時刻歴波形を示す. 各レベルの重心 時刻のずれ，ならびに継続時間の伸びが震央距離に伴い顕著になることを 反映して, 波形全体の継続時間が伸びている事がわかる. また，長周期成分 が相対的に遅れる事により，地震波の後半では長周期成分が優勢となること が速度波形に顕著に見られ，振動数に関する非定常性が実現されているこ とがわかる. エネルギーの減衰による振幅の减少は, $\Delta=10 ; 30,100 \mathrm{~km}$ での Fukushima and Tanaka ${ }^{21)}$ の距離减衰式による最大加速度 297, 126, 26gal より は小さめではあるが，振幅に関する既往の統計的な評価と整合的であること がわかる。

\section{5. まとめ}

本論文では, 地震動記録の回帰分析によりウェーブレット係数を直接的に モデル化し, 非定常性を有する模擬地震動を作成する手法を提案した. 本 手法を用いることにより，従来考慮の外に置かれてきたスペクルル振幅の変化 に起因する時間軸上の分散への寄与も含めて, ウェーブレットのレベルに対 応した振動数帯域ごとの継続時間を表現することができる.

本手法においては，振動数帯域の重なりが極小の Sincウェーブレットをマ ザーウェーブレットに用いることにより, 各パラメータ評価におけるレベル間の 独立性を高め, レベルと振動数帯域のより直接的な対応つけけを可能とした. それに伴って, Sinc ウェーブレットを用いたウェーブレット変換の効率的な計 算方法を示し，時刻歴データから評価されるエネルギーおよび経時特性パラ メータをウェーブレット逆変換を用いずに, ウェーブレット俰数で定式化した. さらに,これらの定式化が観測データについて成立することを数值的にも確 認し，限られたデータセットではあるが，作成した模擬地震動の非定常性が 合理的であることを示した.

なお, 本研究で用いたウェーブレットのレベルに対応した振動数帯域は, 実際の各種波動の卓越振動数に対応するものでないが, 統計的手法の範疇 で使用する限りにおいて十分に実用的な非定常特性を付与すると考えられ る. 今後は, 多くの観測記録を用いて, 多重震源による地震動などをより合理 的にモデル化するためのウェーブレット保数自乗の分布形状を検討し，地域， 表層地質, 震源メカニズム, 震源深さ, 震源距離等の各種パラメータを含む 振動数帯域別の加速度パワー及び経時特性パラメータモデルを構筑する予 定である.

\section{謝辞}

本論文の作成に当たり, 防災科学技術研究所の強震ネットワークK-NETなら びに気象庁 87. 型電磁式強震計のデータを利用しました. 記して謝意を表し ます.

\section{参考文献}

1) 田冶見宏:建案振動学, ユロナ社, 1965

2）和泉正哲, 勝倉裕: 地震動の位相情報に関する基礎的研究，日本建築学会論文報 告集第 327 号, pp.20-27, 1983.5 .

3）伊山潤, 桑村仁:フェイルセーフ構造の耐震性に及ぼす地震動位相特性の影響, 日本建築学会構造系論文集, 第 522 号, pp.13-20, 1999.8.

4) 大崎順彦:原子力発電所設計用の基準地震動評価に関するガイドライン, 主として 大崎スペクトルについて, ORI 研究報告 84-01, 1984.

5) 佐藤智美, 佐藤俊明, 植竹富一, 菅原良次: 群遅延時間を用いたやや長周期地震 動の経時特性評価のための基礎的研究，日本建築学会構造系論文集，第 480 号， pp.57-65, 1996.2.

6)佐藤智美, 植竹富一, 菅原良次:群遅延時間を用いたやや長周期地震動の経験的 経時特性モデルに関する研究, 日本建築学会構造系論文集, 第493 号, pp.31-39, 1997.3.

7) 佐々木文夫, 前田達哉:デー夕解析におけるウェーブレット変換の基本的性状の検 討, 日本建築学会構造系論文報告集, 第453 号, pp.197-206, 1993.11.

8）佐藤忠信, 室野用隆, 西村昭彦: 観剆波に基づく地震動の位相スペクトルのモデル 化, 土木学会論文集, No.640/1-50, pp.119-130, 2000.1.

9) 佐藤忠信, 室野罚隆: 位相情報を用いた地震動のシミュレーション法, 土木学会諭 文集, No.675/-55, pp.113-123, 2001.4.

10) 伊山潤, 桑村仁:ウェーブレット逆変換による模擬地震動の作成, 日本建築学会構 造系論文集, 第 502 号, pp.47-54, 1997.12.

11）佐々木文夫, 前田寿朗, 山本佳史:Sinc ウェーブレットを用いた模擬地祳動作成手 法の研究(その1〜その3), 日本建築学会学術講演梗概集, 構造 II, 関東, pp.29-34, 2001.

12) I. Daubechies : Ten Lectures on Wavelets, SLAM, CBMS-NSF, 1992.

13) F. Sasaki and M. Yamada : Biorthogonal Wavelets Adapted to Integral Operators and Their Applications, JJIAM, Vol. 14, No. 2, pp.257-277, 1997.

14) 杉原正顕: 二重指数関数型変数変換を用いたSinc 関数近似, 京都大学数理解析研 究所請究録, No.990, 1997.

15) 佐々木文夫:ウェーブレット変換とその数値処理について, 日本建築学会学術講演 梗概集，情報システム技術，東北，pp.431-432，2000。

16) G.G.Walter:Wavelets and other orthogonal systems with applications, CRC. Press Inc., 1994.(邦郡:棉原他:ウェーヴレットと直交関数系, 東京電機大学出版局, 2001)

17) 佐々木文夫, 前田達哉, 山田道夫:ウェーブレット変換を用いた時系列データの解 析, 構造工学論文集, 日本建築学会, Vol. 38B, pp.9-20, 1992.

18）山口昌哉, 山田道夫:ウェーブレット解析, 科学, 岩波書店, Vol. 60 , No. 6 , pp.398-405, 1990.

19)、澤田純男, 盛川仁, 土岐雷三, 横山圭樹:地震動の位相スペクトルにおける伝播特 性・サイト特性の分碓, 第 10 回日本地票工学シンポジウム, pp.915-921, 1998.

20) 伊山潤, 桑村仁:ウェーブレット変換による地震動の時間一周波数解析, 日本建築 学会構造采論文集, 第 514 号, 59-64, 1998.12.

21) Fukushima, $Y$. and $T$. Tanaka, A new attenuation relation for peak horizontal acceleration of strong earthquake ground motion in Japan, Bull. Seism Soc. Am, 84,pp.757-783, 1990.

(2001年 7 月 9 日原稿受理, 2001 年11月12日採用決定) 